Primljen / Received: 23.1.2018. Ispravljen / Corrected: 10.5.2018.

Prihvaćen / Accepted: 24.6.2018.

Dostupno online / Available online: 30.12.2018.

\section{Confined length of reinforced concrete columns at various axial load levels}

Authors:

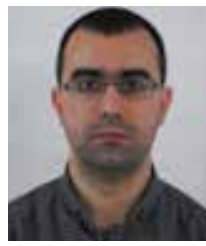

Mounir Ait Belkacem, PhD. CE

National Earthquake Engineering Research Centre, CGS, Algeria

Saad Dahlab University, Civil Engineering Department ait_belkacem1@yahoo.fr

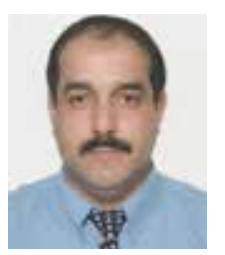

Prof. Hakim Bechtoula, PhD. CE

National Earthquake Engineering Research Centre, CGS, Algeria

bechhakim@gmail.com

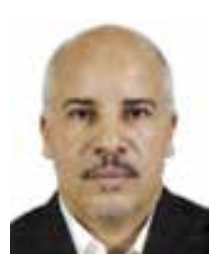

Prof. Nouredine Bourahla, PhD. CE Saad Dahlab University, Algeria Civil Engineering Department nbourahla@univ-blida.dz

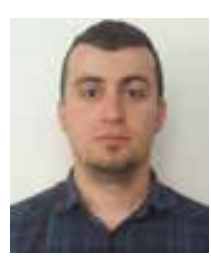

Adel Ait Belkacem, MCE

Bab Ezzouar University of Science \& Technology Adel.AitBelkacem@keller-algerie.com

\begin{abstract}
Preliminary note
Mounir Ait Belkacem, Hakim Bechtoula, Nouredine Bourahla, Adel Ait Belkacem

Confined length of reinforced concrete columns at various axial load levels

The seismic performance of reinforced concrete columns subjected to various levels of axial load is assessed in the paper. An equation relating the confined region to the applied axial load is proposed and compared to the Algerian seismic code RPA99/V2003 specifications, based on the concrete spalling length measured on 16 specimens under different axial load ratios, obtained from the experiments. Results indicate that the length of the confined region of a column subjected to high axial load is underestimated in the above mentioned specifications.
\end{abstract}

Key words:
reinforced concrete columns, axial load, confined region, ductility

Prethodno priopćenje

Mounir Ait Belkacem, Hakim Bechtoula, Nouredine Bourahla, Adel Ait Belkacem

Duljina kritičnog područja AB stupova pri različitim razinama uzdužnog opterećenja

U radu se procjenjuje seizmičko ponašanje AB stupova pri različitim razinama uzdužnog opterećenja. Na temelju rezultata ispitivanja provedenih na ukupno 16 uzoraka AB stupova izloženih različitim razinama uzdužnog opterećenja, predložena je jednadžba koja povezuje duljinu kritičnog područja s primijenjenim uzdužnim opterećenjem, te je uspoređena s alžirskim normama za potres RPA99/V2003. Rezultati su pokazali da je prema navedenim normama duljina kritičnog područja podcijenjena pri visokoj razini uzdužne sile.

Ključne riječi:

armiranobetonski stupovi, uzdužno opterećenje, kritično područje, duktilnost

Vorherige Mitteilung

Mounir Ait Belkacem, Hakim Bechtoula, Nouredine Bourahla, Adel Ait Belkacem

\section{Länge des kritischen Bereichs von Stahlbetonpfeilern bei unterschiedlichen Niveaus der Längsbelastung}

In der Abhandlung wird das seismische Verhalten von Stahlbetonpfeilern bei unterschiedlichen Niveaus der Längsbelastung eingeschätzt. Basierend auf den Ergebnissen der Untersuchungen, die an insgesamt 16 Proben von Stahlbetonpfeilern durchgeführt wurden, die unterschiedlichen Niveaus der Längsbelastung ausgesetzt waren, wird eine Gleichung vorgeschlagen, welche die Länge des kritischen Bereichs mit der angewendeten Längsbelastung verbindet, und diese wurde mit den algerischen Erdbebennormen RPA 99/V2003 verglichen. Die Ergebnisse zeigten, dass gemäß den angeführten Normen die Länge des kritischen Bereichs bei hohem Niveau der Längskraft unterschätzt wird.

Schlüsselwörter:

Stahlbetonpfeiler, Längsbelastung, kritischer Bereich, Dehnbarkeit 


\section{Introduction}

The most frequent damage observed during earthquakes is the crushing of concrete, buckling of longitudinal reinforcement, and opening of transverse reinforcement. This damage is attributed to poor concrete confinement at the RC columns near the column-beam joints, inadequate horizontal reinforcement detailing, and high axial loads.

Over the past 30 years, numerous researchers have conducted investigations aimed at estimating flexural behaviour of reinforced concrete columns. Many parameters, such as the axial load ratio, transverse reinforcement ratio, configuration of transverse reinforcement, main reinforcement ratio, concrete strength, and yield strength of steel reinforcement, can influence seismic performance of reinforced concrete columns [1-16]. The purpose of these research endeavours has been to investigate seismic behaviour of RC columns by analysing the effect of some crucial parameters on the overall performance of $\mathrm{RC}$ columns. Numerical models for specimen testing have been developed and analysed. The analytical results show reasonable agreement with experimental ones. The analysis does not only accurately predict the stiffness, load, and deformation at
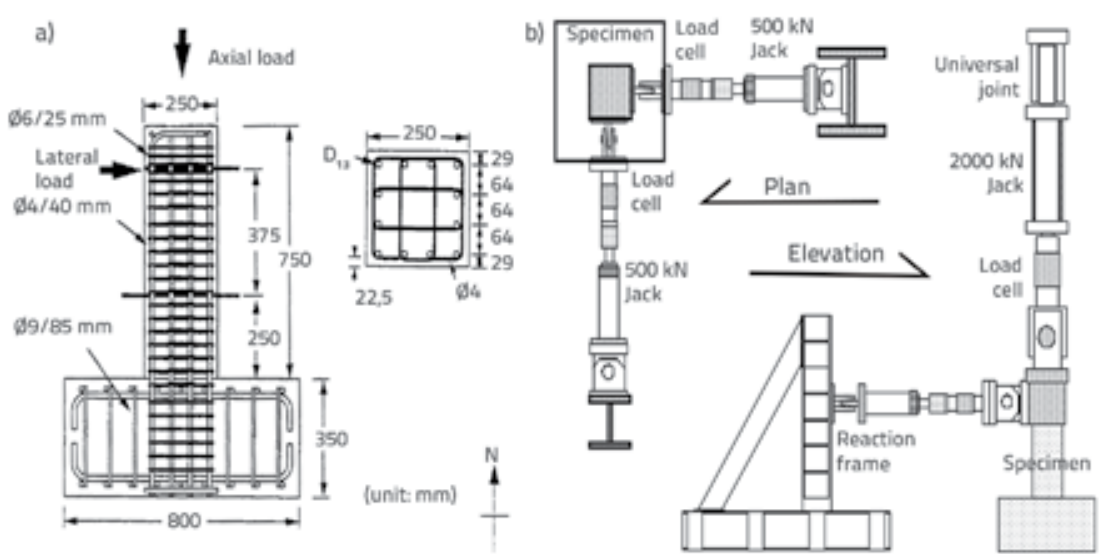

Figure 1. Specimen dimensions and loading system for small specimens [17, 18]: a) Reinforcement configurations; b) Loading system
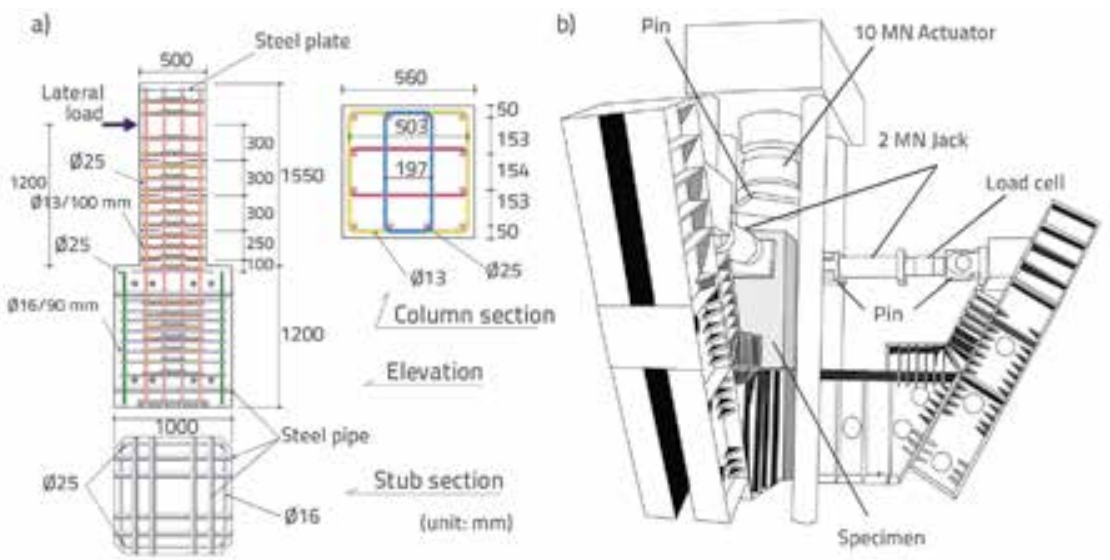

Figure 2. Specimen dimensions and loading system for large specimens [17, 18]: a) Reinforcement configurations; b) Loading system the peak level, but captures the post-peak softening as well. It has been shown that both factors, axial load intensity and transverse reinforcement ratios, have an important influence on the strength, maximum sustained displacement, and energy dissipation capacity of columns.

The effect of the axial load ratio is thoroughly investigated in this paper through analysis of experimental results. Furthermore, sixteen cantilever column models with a square section as shown in Figure 1 and Figure 2 are tested under quasi-static unidirectional and bi-directional displacement, combined with different axial load level [17-18].

Finally, equation relating the confined region to the applied axial load intensity is proposed and compared to those recommended in the current Algerian seismic code RPA 99/v2003, Eurocode 8, and $\mathrm{ACl}$ 315. [19-21].

\section{Material characteristics and test setup}

In this paper, sixteen cantilever reinforced concrete columns of square section were subjected to unidirectional and bidirectional horizontal loading with different axial load ratio. The specimens were designed to fail in flexure. Loads were transferred to the specimens using three (03) hydraulic jack systems that applied orthogonal horizontal displacements at the top, as shown in Figure 1 and Figure 2. Test variables and specimen dimensions are summarized in Table 1. Longitudinal and transverse steel reinforcement mechanical characteristics and concrete compression strength are also shown in this table. Two cycles were applied at each of the following rotation angles $0.25 \%, 0.5 \%, 1 \%, 1.5 \%, 2 \%, 3 \%$ and 4 $\%$ for small scale specimens. Large scale specimens were loaded with two cycles at the following rotation angles $0.25 \%$, $0.5 \%, 0.75 \%, 1 \%, 2 \%, 3 \%$, and $4 \%$. The specimen L2NVC was subjected with four (04) cycles as follows $0.25 \%(4), 0.5$ $\%(4), 0.25 \%(2), 0.75 \%(4), 1 \%(4), 0.75$ $\%(2), 2 \%(4), 3 \%(4), 2 \%(2)$, and $4 \%(4)$. The variation of axial load depends on the applied moment $[17,18]$.

\section{Experimental results}

\subsection{Effect of axial load on normalized horizontal load - rotation angle hysteresis loops}

An increase in constant axial load from to for specimens under a unidirectional 
Table 1. Geometric characteristics, loading and reinforcement ratios of tested columns [17, 18]

\begin{tabular}{|c|c|c|c|c|c|c|c|c|c|}
\hline \multirow[b]{2}{*}{ No } & \multirow[b]{2}{*}{$\begin{array}{c}\text { Specimen } \\
\text { designation }\end{array}$} & \multicolumn{5}{|c|}{ Specimen configuration } & \multicolumn{3}{|c|}{ Test variables } \\
\hline & & $\begin{array}{c}\text { Column } \\
\text { width D } \\
\text { [mm] }\end{array}$ & $\begin{array}{c}\text { Shear } \\
\text { span L } \\
{[\mathrm{mm}]}\end{array}$ & $\begin{array}{c}\text { Concrete } \\
\text { strength } f_{c}^{\prime} \\
\text { [MPa] }\end{array}$ & $\begin{array}{l}\text { Longitudinal } \\
\text { rebar } \\
\text { (ratio) }\end{array}$ & $\begin{array}{l}\text { Shear } \\
\text { rebar } \\
\text { (ratio) }\end{array}$ & $\begin{array}{l}\text { Axial force (axial } \\
\text { force level in } \\
\left.\qquad f_{c}^{\prime} D^{2}\right)\end{array}$ & $\begin{array}{c}\text { Slope in } \\
\text { normalized } \\
\text { moment - axial } \\
\text { force relation }\end{array}$ & $\begin{array}{c}\text { Lateral } \\
\text { loading } \\
\text { directions }\end{array}$ \\
\hline 1 & D1N3 & \multirow{4}{*}{250} & \multirow{8}{*}{625} & \multirow{4}{*}{37.6} & \multirow{4}{*}{$\begin{array}{c}12-\varnothing 13 \\
2.44 \% \\
461 \mathrm{MPa}\end{array}$} & \multirow{4}{*}{$\begin{array}{c}\varnothing 4 / 40 \\
0.50 \% \\
485 \mathrm{MPa}\end{array}$} & Constant (0.3) & \multirow{4}{*}{0} & \multirow{2}{*}{ Uni } \\
\hline 2 & D1N6 & & & & & & Constant (0.6) & & \\
\hline 3 & D2N3 & & & & & & Constant (0.3) & & \multirow[b]{2}{*}{$\mathrm{Bi}$} \\
\hline 4 & D2N6 & & & & & & Constant (0.6) & & \\
\hline 5 & D1NVA & \multirow{4}{*}{242} & & \multirow{4}{*}{26.8} & \multirow{4}{*}{$\begin{array}{c}12-\varnothing 13 \\
2.60 \% \\
467 \mathrm{MPa}\end{array}$} & \multirow{4}{*}{$\begin{array}{c}\emptyset 4 / 40 \\
0.52 \% \\
604 \mathrm{MPa}\end{array}$} & \multirow{4}{*}{ Varied (0-0.6) } & 1.39 & \multirow{2}{*}{ Uni } \\
\hline 6 & D1NVB & & & & & & & 2.79 & \\
\hline 7 & D2NVA & & & & & & & 1.04 & \multirow{2}{*}{$\mathrm{Bi}$} \\
\hline 8 & D2NVB & & & & & & & 1.66 & \\
\hline 9 & L1D60 & \multirow{4}{*}{600} & \multirow{8}{*}{1200} & \multirow{4}{*}{39.2} & \multirow{4}{*}{$\begin{array}{c}12-\varnothing 25 \\
1.69 \% \\
388 \mathrm{MPa}\end{array}$} & \multirow{4}{*}{$\begin{array}{c}\varnothing 13 / 100 \\
0.85 \% \\
524 \mathrm{MPa}\end{array}$} & \multirow{2}{*}{ Constant (0.6) } & \multirow{2}{*}{0} & \multirow{2}{*}{ Uni } \\
\hline 10 & L1N60 & & & & & & & & \\
\hline 11 & L1NVA & & & & & & & & \\
\hline 12 & L2NVA & & & & & & Varied (0-0.6) & 2.47 & $\mathrm{Bi}$ \\
\hline 13 & L1N6B & \multirow{4}{*}{560} & & \multirow{4}{*}{32.2} & \multirow{4}{*}{$\begin{array}{c}12-\varnothing 25 \\
1.94 \% \\
388 \mathrm{MPa}\end{array}$} & \multirow{4}{*}{$\begin{array}{c}\varnothing 13 / 100 \\
0.91 \% \\
524 \mathrm{MPa}\end{array}$} & \multirow{2}{*}{ Constant (0.6) } & \multirow[b]{2}{*}{0} & \multirow{2}{*}{ Uni } \\
\hline 14 & L2N6B & & & & & & & & \\
\hline 15 & L2NVB & & & & & & & & $\mathrm{Bi}$ \\
\hline 16 & L2NVC & & & & & & Varıed (0-0.6) & 3.36 & $\mathrm{BI}$ \\
\hline
\end{tabular}

horizontal load will result in the reduction of deformability capacity, defined in this study as the deformation corresponding to $20 \%$ drop in flexural strength, and in the increase of flexural strength degradation after the peak. However, the hysteresis loops for specimens under the high axial load will be fatter than those for specimen under a moderate axial load, which show some pinching as illustrated in Figure 3.

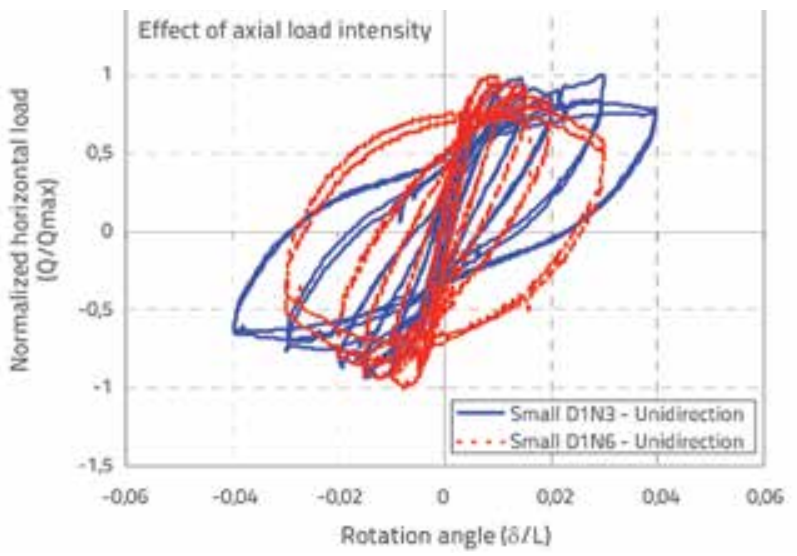

Figure 3. Small-scale specimens under constant axial load and unidirectional horizontal load: Normalized horizontal load vs Rotation angle [17, 18]

\subsection{Effect of loading path on the normalized horizontal load - rotation angle relationship}

Bi-directional loading reduced the flexural strength capacity for small-scale specimens under and increased the dissipated energy as illustrated in Figure 4(a) and Figure 4(b). However, for specimens under the axial load and bi-directional horizontal loading, flexural strength, deformability and dissipated energy, were reduced as illustrated in Figure 4(c) and Figure 4(d).This may be attributed to concrete damage, since for bi-directional loading, concrete located in the 4 faces at the column base will be subjected to high compression force, whereas only 2 faces are subjected to high compression for unidirectional loading.

\subsection{Axial strain-normalized curvature relationship}

The axial load intensity had a significant effect on the column shortening as shown in Figure 5. The axial strain was defined as the elongation/shortening measured at the column base for a distance equal to the column depth, divided by the column depth. As can be seen, specimen D1N3, unidirectionally loaded and subjected to a moderate axial load, exhibited more elongation, $0.35 \%$, than shortening, $0.15 \%$. In the same manner, specimen D1N6, subjected to 

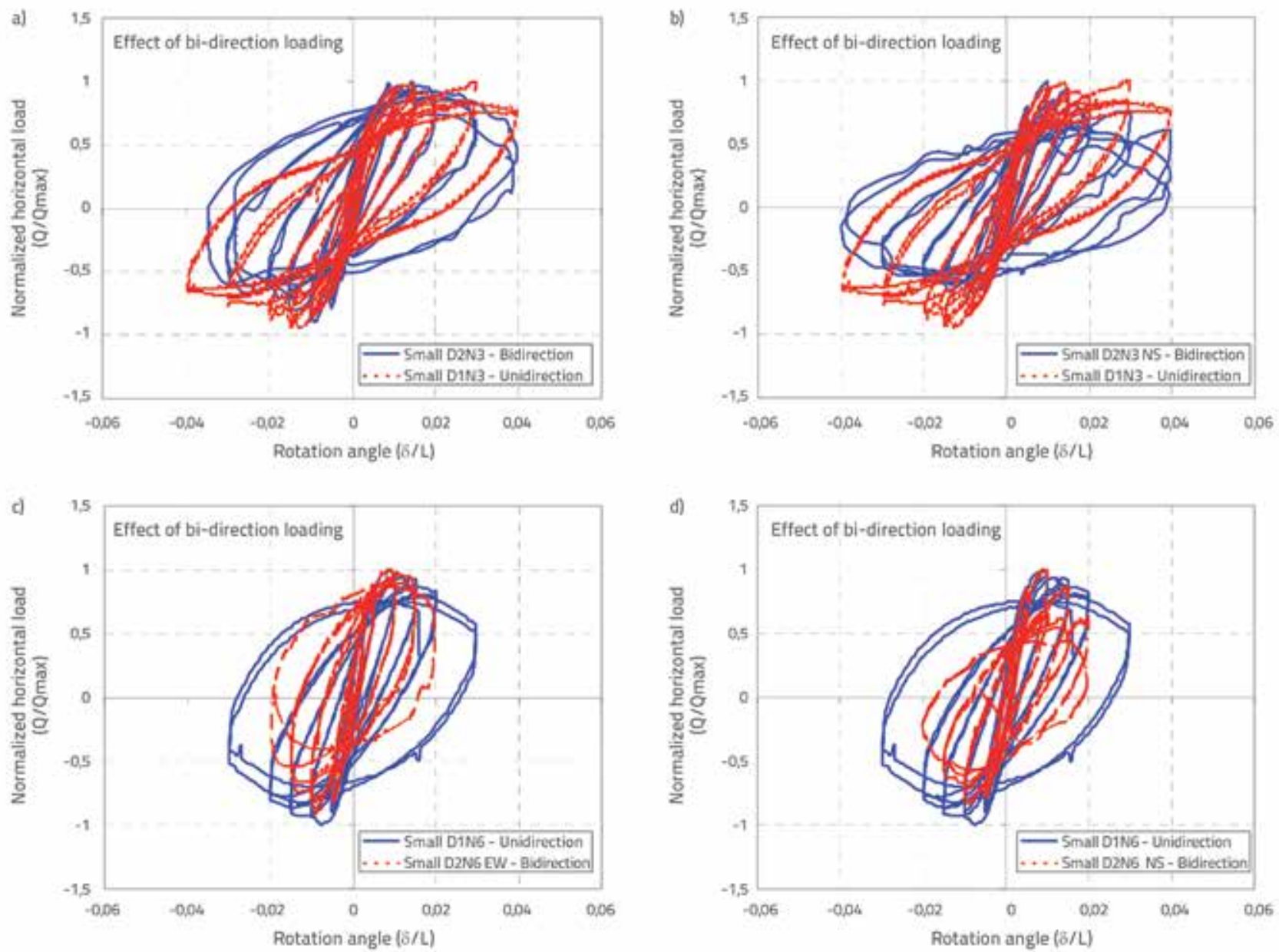

Figure 4. Effect of loading path on normalized horizontal load-drift relationship [17, 18]: a) D1N3 vs. D2N3 -EW; b) D1N3 vs. D2N3 -NS; c) D1N6 vs. D2N6 -EW; d) D1N6 vs. D2N6 -NS
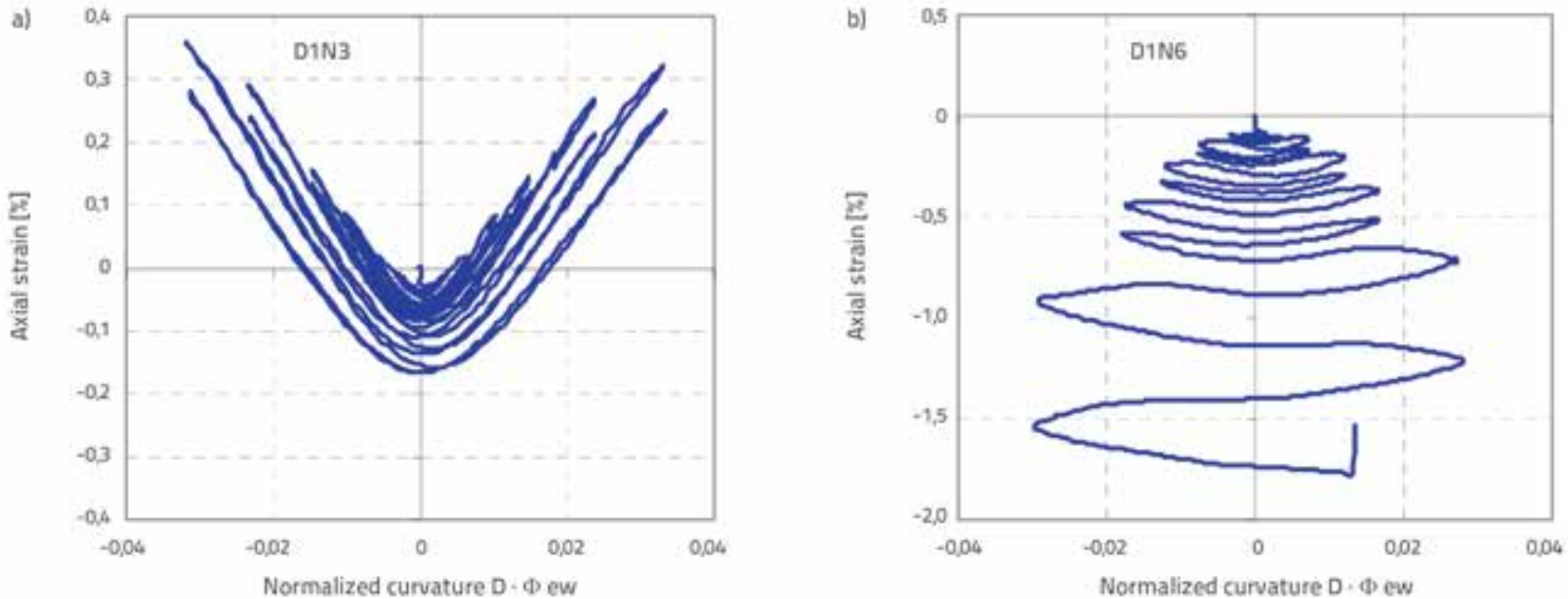

Figure 5 Small-scale specimens under constant axial load and unidirectional horizontal load: axial strain-normalized curvature relationship $[17,18]$ : a) D1N3; b) D1N6

axial load two times greater compared to specimen D1N3, showed only shortening throughout the test process. It is worth noting here that the bi-directionally loaded specimen
D2N6 exhibited only shortening from the beginning of the test, even though the specimen was under a moderate axial load, as shown in Figure 6. 

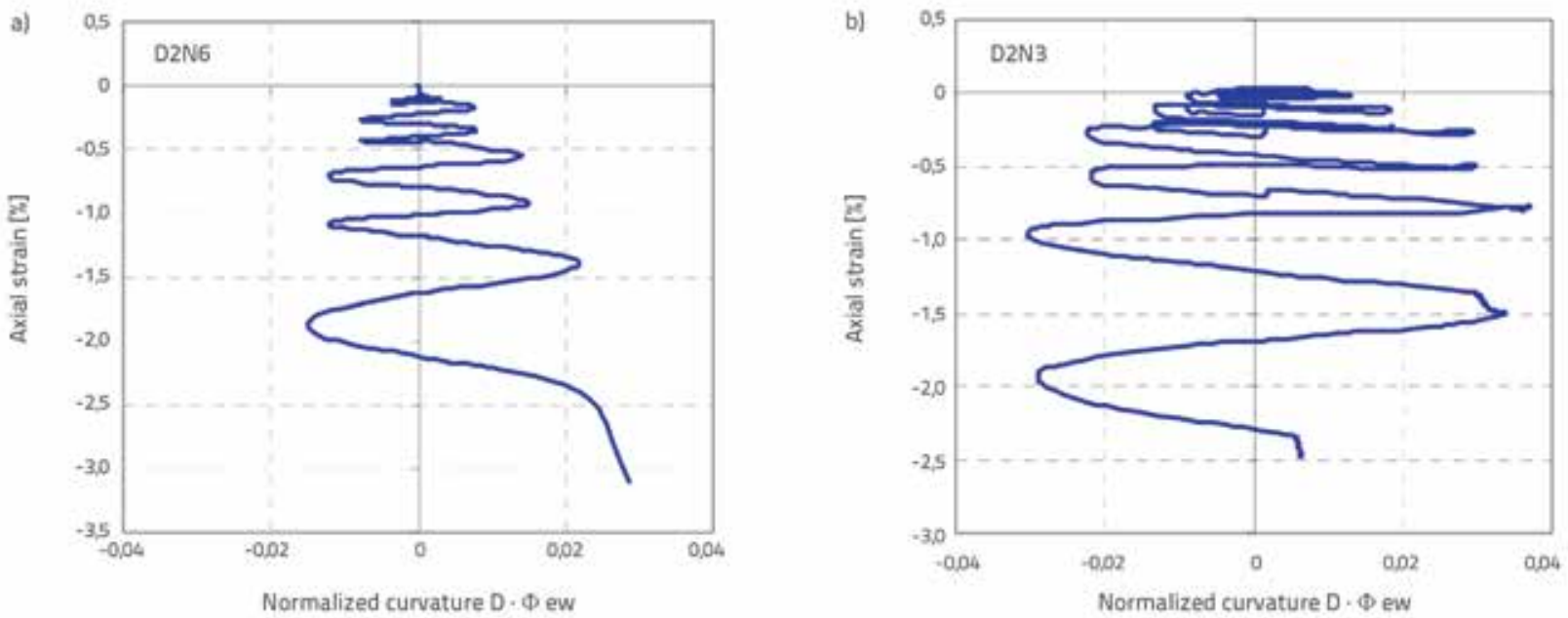

Figure 6. Small-scale specimens under constant axial load and bidirectional horizontal load: axial strain-normalized curvature relationship $[17,18]$ : a) D2N6; b) D2N3

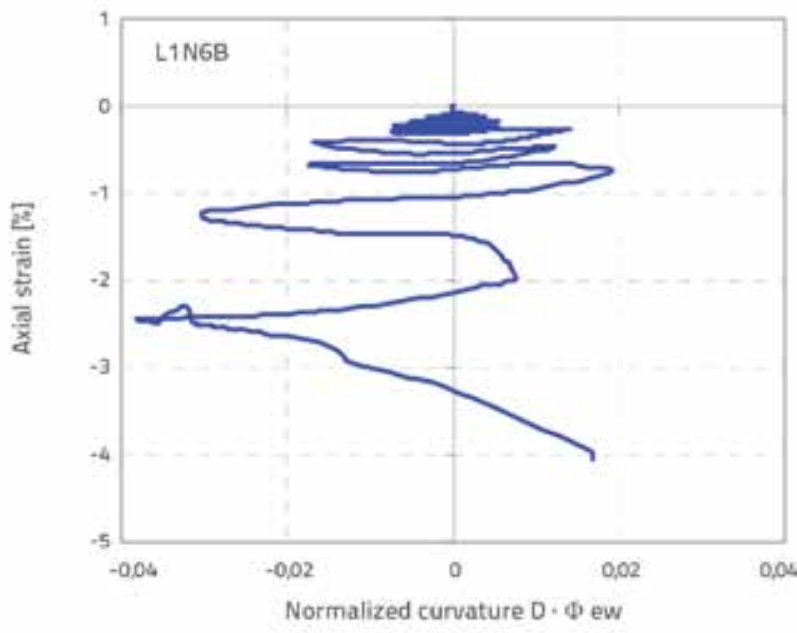

Figure 7. Large-scale specimens under constant axial load and unidirectional horizontal load: axial strain-normalized curvature relationship $[17,18]$

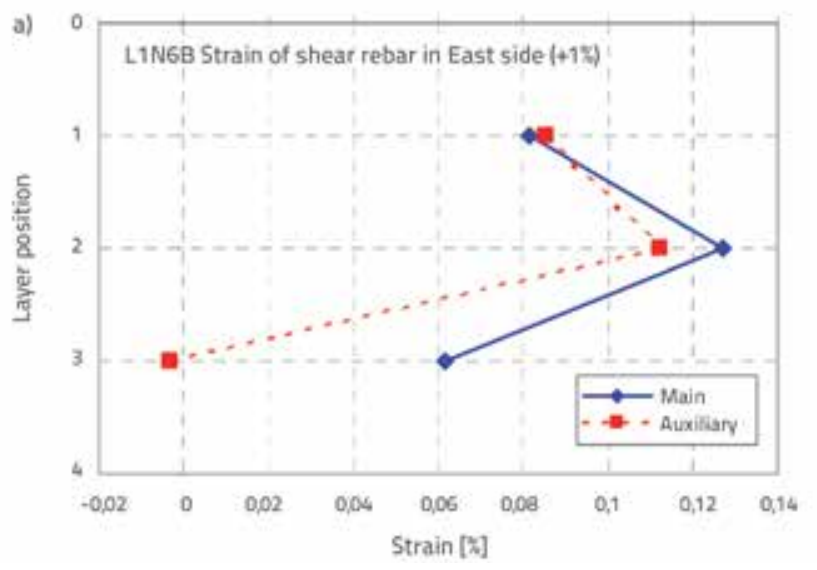

It can be seen that the loading pattern, as well as the axial load level, have a significant influence on the seismic performance of columns.

\subsection{Strain distribution in longitudinal and transverse reinforcements}

During the test, concrete cover spalled first, which was followed by buckling of longitudinal corner reinforcement. As the test progressed, concrete started crushing at the corners and gradually the load carrying capacity was reduced as damage penetrated toward the column core. This state can be seen in Figure 8, which shows strain distribution at the east side of shear reinforcement at $1 \%$ and $3 \%$ drift, respectively, at 3 different hoops locations along the column height, as shown in Figure 9.b. The strain of the external hoop started to reduce with an increase in strain of the internal hoop. This means that concrete at the periphery of the core was severally damaged and, hence, the effective concrete

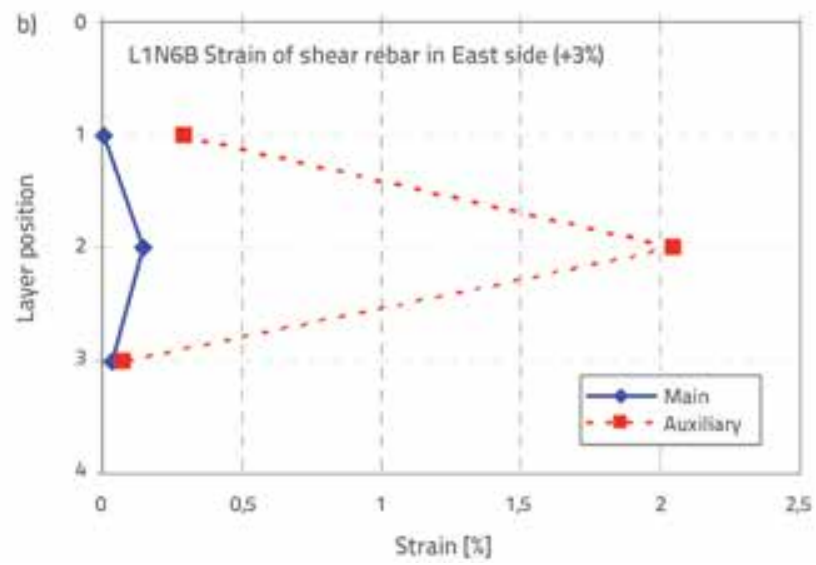

Figure 8. Strain distribution in transverse reinforcement for L1N6B $[17,18]$ : a) At $1 \%$ drift; b) At $3 \%$ drift 
area reduced considerably. Taking into account the observed damage and the results found using the shear reinforcement strain distribution, the column section was classified into several distinct areas. These areas are shown in Figure 10 and classified from 1 to 4 . The number in each area indicates its crushing order.
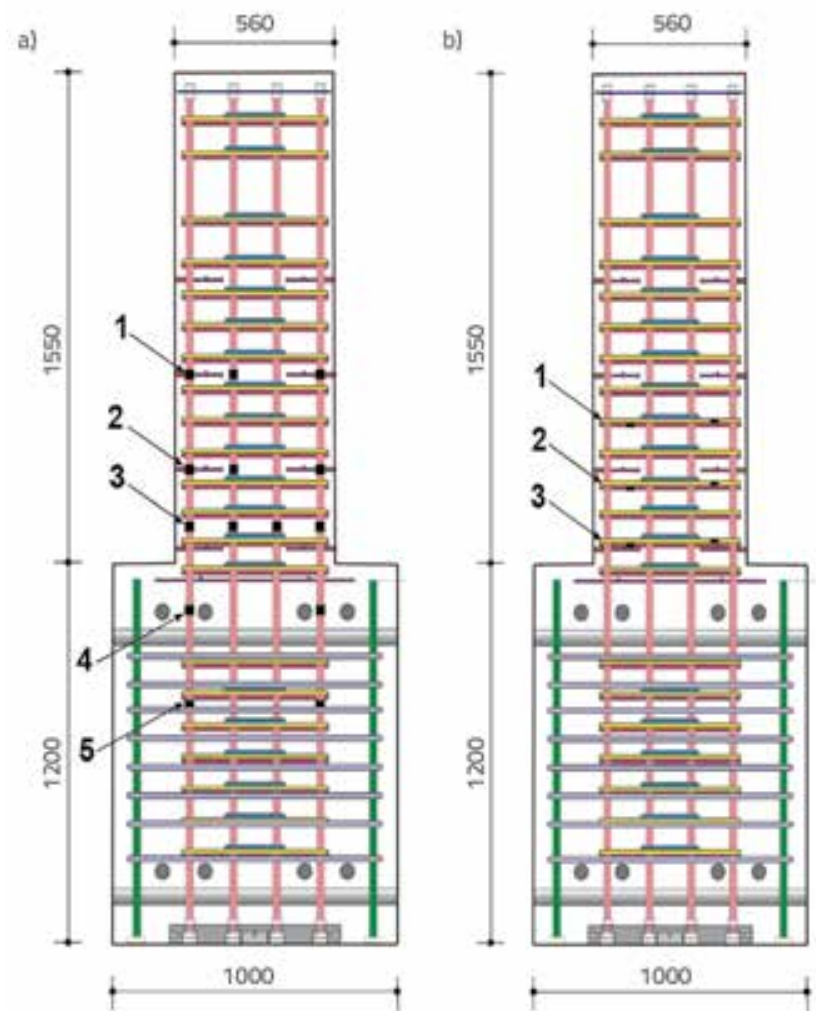

Figure 9. Position of strain gauges (layer positions) [17, 18]: a) Longitudinal reinforcement; b) transverse reinforcement
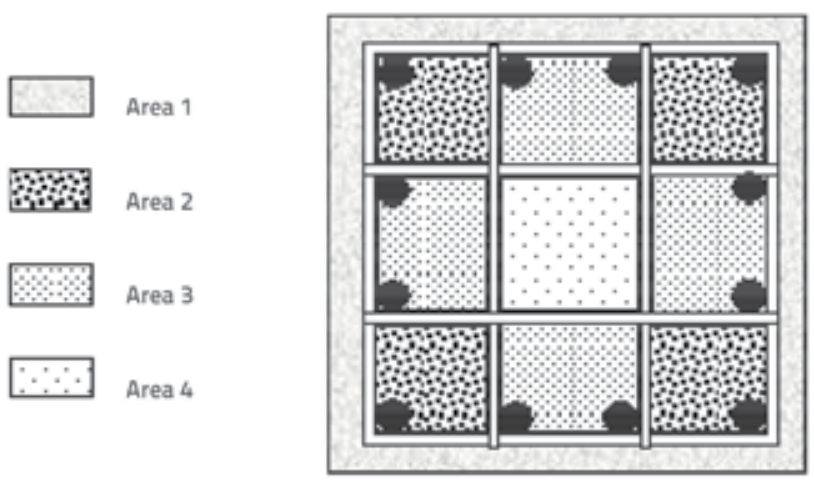

Figure 10. Zoning of damage progress

Strain distribution for longitudinal corner bars over the height, is shown in Figure 11 at $2 \%$ drift. The maximum-recorded strain took place either in the second or third layer shown in Figure 8.a.

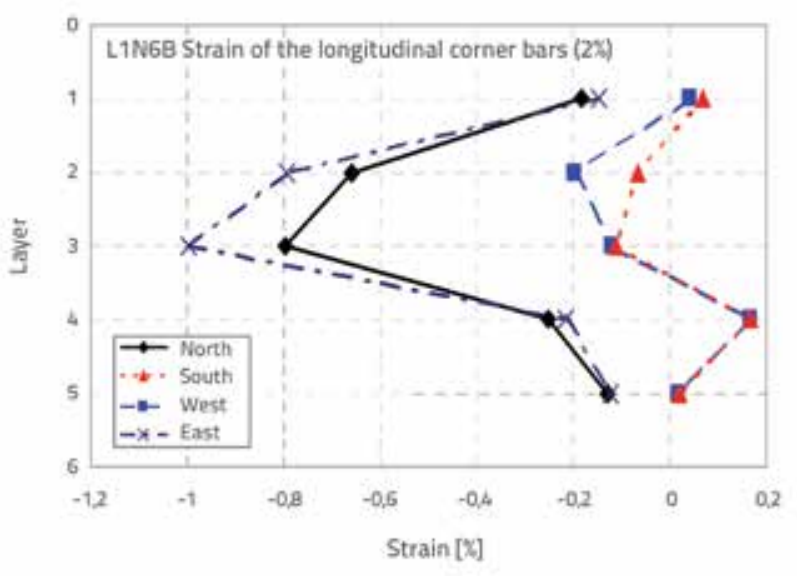

Figure 11. Distribution of strain in longitudinal reinforcement [17, 18]

\section{Observed damage}

For specimen L1D60 subjected to unidirectional loading in the north-south direction and presenting an axial load ratio of 60 $\%$, the spalling of the cover concrete reached a height of 1.5 of the column depth. Damage to the cover concrete (spalling) was observed at the base of specimen L1N60 for a height of 1 to 1.5 of the column depth. The north-east and north-west corner longitudinal rebar was buckled at the height of 0.5 of the column depth from the base. A slight buckling of the corner longitudinal rebar was observed for specimen D1N6 and spalling of the cover concrete reached a height of 1.0 to 1.4 of the column depth from the base. For specimen L1N6B, only two longitudinal rebar out of 12 reinforcement bars buckled at the end of the test, and 4 to $5 \mathrm{~mm}$ crack widths were measured at the west side of the column. Spalling of the cover concrete reached a height of 0.5 to 1.4 of the column depth. For the specimen subjected to bidirectional loading, L2N6B, concrete spalled at the column base between 1.1 to 1.6 of the column depth at $3 \%$ rotation angle. Vertical cracks were observed during the test reaching 1.6 of the column depth in height. Ten longitudinal rebars out of twelve reinforcement bars buckled at the end of the test. Buckled bars exhibited an "S" shape between 0.2 and 0.8 of the column depth from the base.

The following remarks can be made based on the observed damage of specimens with different scale (small/large) of columns:

- The spalled concrete zone increases significantly with an increase in the scale of columns (large scale) as shown in Figure 12. It can clearly be seen that damage is concentrated at the lower part for a small scale column.

- Buckling of the longitudinal rebar is more important in case of large scale columns for the same displacement, as illustrated in Figure 13.

It can be concluded that the scale effect also has a significant influence on the seismic performance of columns, especially on the damage pattern. 


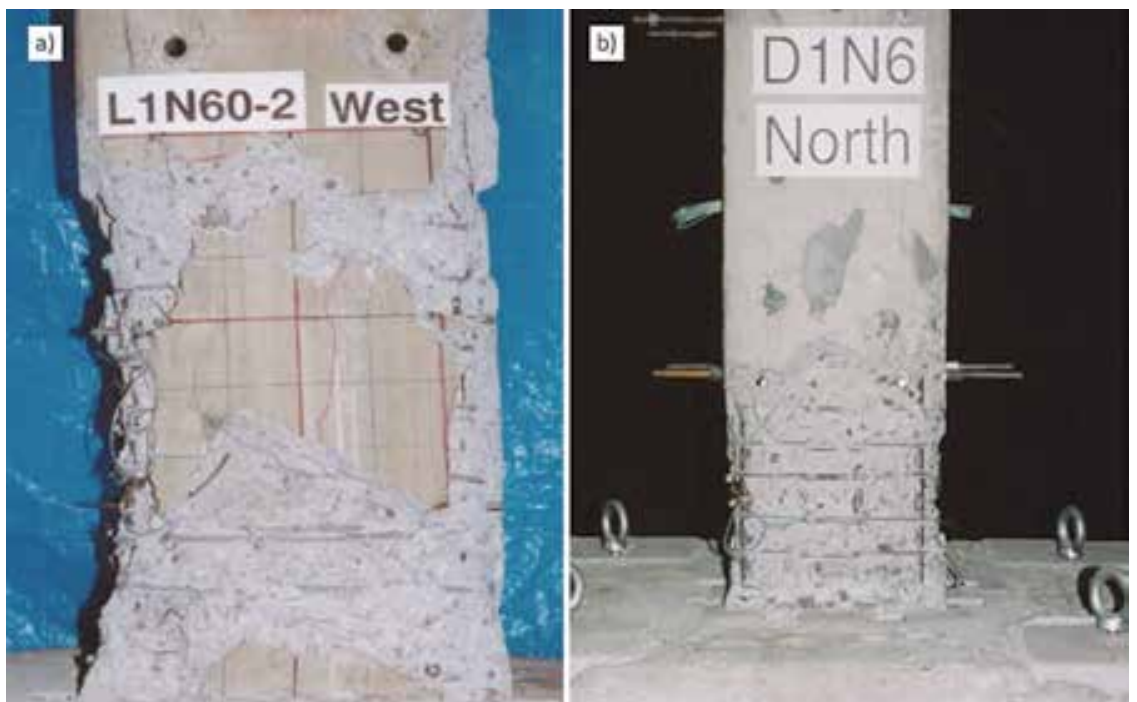

Figure 12. Damage pattern for specimens under constant axial load and unidirectional loading [17, 18]: a) Large-scale; b) Small-scale

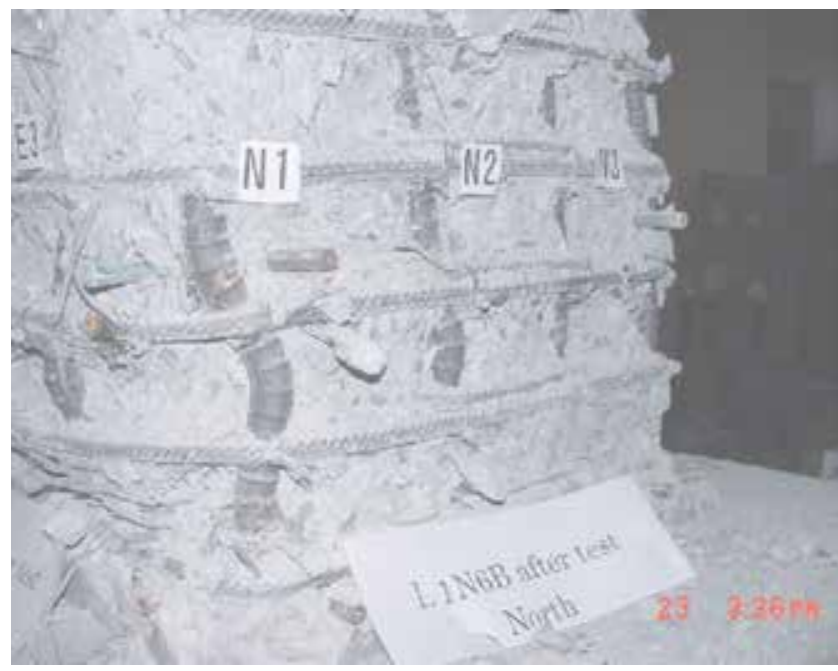

Figure 13. Expansion of shear reinforcement and crashing of corners concrete $[17,18]$

\section{Proposed equation for confined region of column}

The Algerian seismic code RPA 99/v2003, ACl 315, and Eurocode 8 [19-21], propose a confined (tied spacing of transverse reinforcement) length region, for the column near the columnbeam joints and at the column base, respectively, as follows:

$L_{c}=\operatorname{Max}\left(\frac{h_{e}}{6} ; D ; 60 \mathrm{~cm}\right)$

$L C=\operatorname{Max}\left(D ; \frac{h_{e}}{6} ; 50 \mathrm{~cm}\right)$

$L_{c}=\operatorname{Max}\left(1.5 D ; \frac{h_{\mathrm{e}}}{6} ; 60 \mathrm{~cm}\right)$
Where, $h$ is the clear height of the column, and $D$ is the largest crosssectional dimension of the column.

As given in eqs. (1), (2) and (3), the confined zone is independent of the axial load ratio, which is not consistent with the observed experimental results. In 1989, S. Watson [22], proposed a confined region that takes into account the axial load intensity given by:

$L_{c}=\left(1+2.8 \frac{N}{f_{c}^{\prime} A_{g}}\right) D$

A required confined length is proposed using the measured concrete spalling length for 16 specimens as shown in Table 2 for different axial load ratios.

Table 2. Damaged length [Lc ( \%D)] [17, 18]

\begin{tabular}{|c|c|c|}
\hline Specimen & $\mathbf{f}_{{ }^{\prime}{ }^{\prime}{ }_{\mathbf{g}}}$ & $\mathbf{L}_{\mathbf{c}}[\% \mathrm{D}]$ \\
\hline D1N3 & 0.3 & 0.84 \\
\hline D2N3 & 0.3 & 1.16 \\
\hline D1NVA & 0.3 & 1 \\
\hline D1NVB & 0.3 & 0.58 \\
\hline D2NVA & 0.3 & 0.88 \\
\hline D2NVB & 0.3 & 1.19 \\
\hline L1NVA & 0.3 & 1.5 \\
\hline L2NVA & 0.3 & 1.5 \\
\hline L2NVB & 0.3 & 1.52 \\
\hline L2NVC & 0.3 & 1.61 \\
\hline D1N6 & 0.6 & 1.36 \\
\hline D2N6 & 0.6 & 1.8 \\
\hline L1D60 & 0.6 & 1.5 \\
\hline L1N60 & 0.6 & 1.5 \\
\hline L1N6B & 0.6 & 1.43 \\
\hline L2N6B & 0.6 & 1.61 \\
\hline & & \\
\hline & 0.3 & \\
\hline
\end{tabular}

The governing equation can be written as:

$L_{c}=\left(1.42+0.63 \frac{N}{f_{c}^{\prime} A_{g}}\right) D$

The proposed equation gave values $0 L_{c}=1,42 \mathrm{D}$ and $1,8 \mathrm{D}$ for $N / f_{c}^{\prime} A_{g}=0$ and 0,6 , respectively. For the same axial load ratios, Watson's equation gives values of $L_{c}=1,0 \mathrm{D}$ and 2,68D.

Watson's equation and the proposed equation are compared 
Table 3. Confined length codes comparison

\begin{tabular}{|c|c|c|c|c|c|c|c|}
\hline & & & RPA 2003 & Eurocode 8 & ACI 315 & Watson equation & Proposed equation \\
\hline Specimen & $\frac{N}{f_{c}^{\prime} A_{g}}$ & $\begin{array}{l}\text { Section and } \\
\text { length } \\
{[\mathrm{mm}]}\end{array}$ & 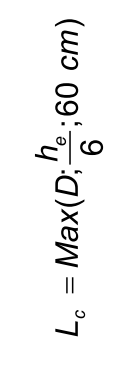 & 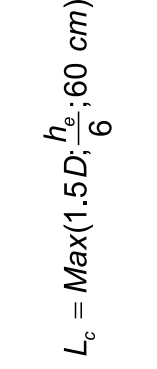 & 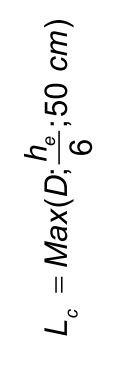 & 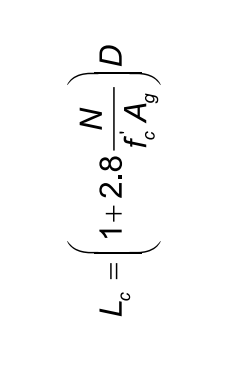 & 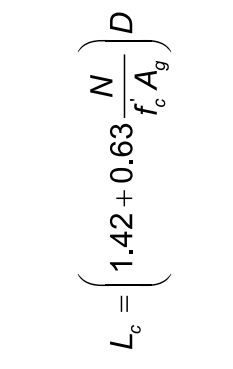 \\
\hline D1N3 & \multirow{10}{*}{0.3} & $D=250$ & 20 & 20 & D & \multirow{10}{*}{$1.84 \mathrm{D}$} & \multirow{10}{*}{$1.6 \mathrm{D}$} \\
\hline D2N3 & & $L=625$ & 2.40 & 2.40 & 20 & & \\
\hline D1NVA & & \multirow{4}{*}{$\begin{array}{l}D=242 \\
L=625\end{array}$} & \multirow{4}{*}{$2.48 \mathrm{D}$} & \multirow{4}{*}{$2.48 \mathrm{D}$} & \multirow{4}{*}{$2.06 \mathrm{D}$} & & \\
\hline D1NVB & & & & & & & \\
\hline D2NVA & & & & & & & \\
\hline D2NVB & & & & & & & \\
\hline L1NVA & & \multirow{2}{*}{$\begin{array}{c}D=600 \\
L=1200\end{array}$} & \multirow{2}{*}{ D } & \multirow{2}{*}{$1.5 \mathrm{D}$} & \multirow{2}{*}{ D } & & \\
\hline L2NVA & & & & & & & \\
\hline L2NVB & & \multirow{2}{*}{$\begin{array}{l}D=560 \\
L=1200\end{array}$} & \multirow{2}{*}{$1.07 \mathrm{D}$} & \multirow{2}{*}{$1.5 \mathrm{D}$} & \multirow{2}{*}{ D } & & \\
\hline L2NVC & & & & & & & \\
\hline L1D60 & \multirow{6}{*}{0.6} & \multirow{2}{*}{$\begin{array}{l}D=600 \\
L=1200\end{array}$} & \multirow{2}{*}{ D } & \multirow{2}{*}{$1.5 \mathrm{D}$} & \multirow{2}{*}{ D } & \multirow{6}{*}{$2.68 \mathrm{D}$} & \multirow{6}{*}{$1.8 \mathrm{D}$} \\
\hline L1N60 & & & & & & & \\
\hline L1N6B & & $D=560$ & D 107 & $15 \mathrm{D}$ & $\mathrm{n}$ & & \\
\hline L2N6B & & $L=1200$ & $1.07 \mathrm{D}$ & 1.50 & D & & \\
\hline D1N6 & & \multirow{2}{*}{$\begin{array}{l}D=250 \\
L=625\end{array}$} & \multirow{2}{*}{$2.4 \mathrm{D}$} & \multirow{2}{*}{$2.4 \mathrm{D}$} & \multirow{2}{*}{$2 \mathrm{D}$} & & \\
\hline D2N6 & & & & & & & \\
\hline
\end{tabular}

with experimental results in Figure 14. As can be seen in the figure, Watson's equation underestimated the confined region for an axial load ratio $N / f_{c}^{\prime} A_{g} \leq 0,2$ and overestimated beyond that value.

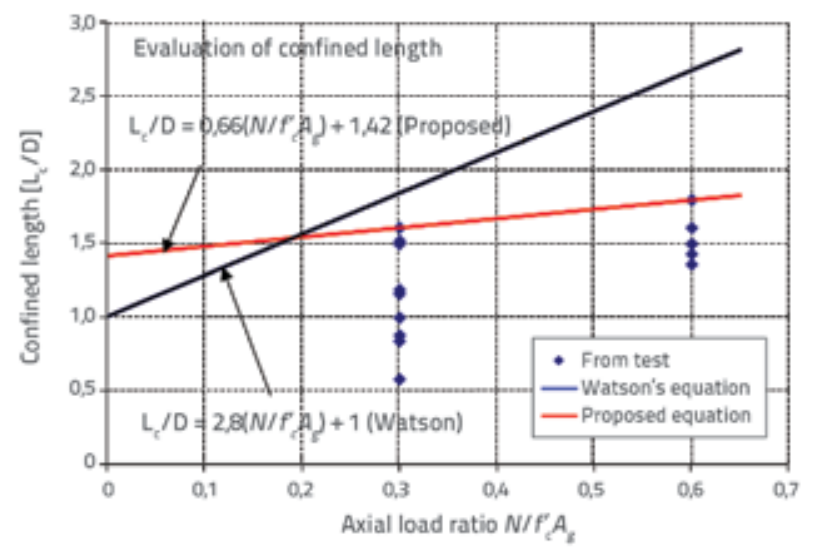

Figure 14. Prediction of confined length, and test results

The observed damage for large-scale specimens indicated that the length of potential plastic hinge to be confined for a column with high axial compression force, $0,6 f_{c}^{\prime} A_{g}$ specified by the current Algerian seismic code RPA99/v2003, is underestimated.
The confined region needs to be extended to prevent failure of column outside the code's specified plastic hinge region.

As an example, the Algerian seismic code, $\mathrm{ACl} 315$, and Eurocode 8, gave for specimen $L 2 N 6 B$, a confined region equal to $1,07 D$, $1,0 D$ and $1,5 D$, respectively, which is less than $1,6 D$ found in the experiment, as shown in Table 3.

\section{Conclusion}

Some of the main results, as obtained by the authors during realisation of several experimental programs focusing on sixteen reinforced concrete columns with different axial load intensities, are presented and discussed in this paper. The main conclusions of this research program are summarized as follows:

- Damage to large-scale specimens observed during the testing shows that the length of potential plastic hinge to be confined for a column with high axial compression force, specified by the current Algerian seismic code RPA 99/ v2003, is underestimated. The confined region needs to be extended to prevent column failure outside of the confined region specified in the code. Based on the data obtained in the scope of this experimental program, an equation relating the confined region to the column size and the intensity of the applied axial load is proposed. 
- The loading path, unidirectional or bi-directional, has a significant influence on seismic performance of columns, as well as on the damage pattern.

- The cross section of the column was classified from 1 to 4 according to the crushing order, taking into account the observed damage and shear reinforcement results obtained using strain gauges.

\section{REFERENCES}

[1] Azizinamini, A., Corley, W.G., Johal, L.S.P.: Effects of transverse reinforcement on seismic performance of columns, ACI Structural Journal, 89 (1992) 4, pp. 442-450.

[2] Lam, S.S.E., Wu, B., Wong, Y.L., Wang, Z.Y., Liu, Z.Q., Li, C.S.: Drift capacity of rectangular reinforced concrete columns with low lateral confinement, ASCE, Structural Engineering, 129 (2003) 6, pp. 733-742.

[3] Lynn, A.C., Moehle, J.P., Mahin, S.A., Holmes, W.T.: Seismic evaluation of existing reinforced concrete building columns, Earthquake Spectra, 12 (1996) 4, pp. 715-739.

[4] Saatciolglu, M., Ozcebe, G.: Response of reinforced concrete columns to simulated seismic loading, ACI Structural Journal, 86 (1989) 1, pp. 3-12.

[5] Sargin, M., Ghosh, S.K., Handa, V.K.: Effects of Lateral Reinforcement Upon the Strength and Deformation Properties of Concrete, Magazine of Concrete Research, 23 (1971) 75, pp. 99.

[6] Skeikh, S.A., Khoury, S.S.: Confined concrete columns with stubs, ACI Structural Journal, 90 (1993) 4, pp. 414-431.

[1] Wehbe, N.I., Saiidi, M.S., Sanders, D.H.: Seismic performance of rectangular bridge columns with moderate confinement, $\mathrm{ACl}$ Structural Journal, 96 (1999) 2, pp. 248-259.

[8] Xiao, J., Zhang, C.: Seismic behavior of RC columns with circular, square and diamond sections, Constructions and Building Materials, 22 (2008) 5, pp. 801-810.

[9] Su, J., Wang, J.Z.Bai., Wang, W., Zhao, D.: Influence of reinforcement buckling on the seismic performance of reinforced concrete columns, Eng. Struct, 103 (2015), pp. 174-188.

[10] Yuan, F., Wu, Y.F.: Effect of load cycling on plastic hinge length in RC columns, Eng. Struct, 147 (2017), pp. 90-102.

[11] Shirmohammadi, F., Esmaeily, A.: Performance of reinforced concrete columns under bi-axial lateral force/displacement and axial load, Eng. Struct, 99 (2015), pp. 63-77.

[12] Choi, K.K., Truong, G.T., Kim, J.C.: Seismic performance of lightly shear reinforced RC columns", Eng. Struct, 126 (2016), pp. $490-$ 504.
- The concrete spalling zone increases significantly with the scale of the columns. This can clearly be seen through visual inspection of damage.

- Buckling of longitudinal reinforcement is more important in the case of the large-scale columns for the same displacement.
[13] Jing, D.H., Yu, T., Liu, X.D.: New configuration of transverse reinforcement for improved seismic resistance of rectangular RC columns: Concept and axial compressive behavior, Eng. Struct, 111 (2016), pp. 383-393.

[14] Zhenyun, T., Hua, M., Jun, G., Yongping, X., Zhenbao, L.: Experimental research on the propagation of plastic hinge length for multi-scale reinforced concrete columns under cyclic loading, Earthquakes and Structures, 11 (2016) 5.

[15] Bhayusukma, M.Y., Tsai, K.C.: High-strength RC columns subjected to high-axial and increasing cyclic lateral loads, Earthquakes and Structures, 7 (2014) 5, pp. 779-796.

[16] Au, F.T.K., Bai, Z.Z.: Effect of axial load on flexural behaviour of cyclically loaded RC columns, Computers and Concrete, 3 (2006) 4, pp. 261-284.

[17] Bechtoula, H., Kono, S., Watanabe, F.: Experimental and analytical investigation of seismic performance of cantilever reinforced concrete columns under varying transverse and axial loads, JAABE, 4 (2005) 2, pp. 467-475.

[18] Kono, S., Bechtoula, H., Sakashita, M., Tanaka, H., Watanabe, F., Eberhard, M.O.: Damage assessment of reinforced concrete columns under high axial loading, ACI Special Publication, 237 (2006) SP, pp. 165-176.

[19] Ministry of Housing and Urban Planning. Règles parasismique algériennes RPA 99/version 2003.

[20] Eurocode 8: Design of structures for earthquake resistance - Part 1: General rules, seismic actions and rules for buildings, BS EN 1998-1:2004

[21] ACl 315-99: Details and Detailing of Concrete Reinforcement. Reported by ACI Committee 315,1999.

[22] Watson, S., Soesianawati, M.T., Park, R.: Design of reinforced concrete frames of limited ductility, Report 89-4, Department of Civil Engineering, University of Canterbury, Christchurch, New Zealand, pp. 232, 1989. 